\title{
Enantioselective Synthesis of Antiepileptic Agent, (-)-Levetiracetam, through Evans Asymmetric Strategy
}

\author{
K. Chandra Babu, ${ }^{1,2}$ R. Buchi Reddy, ${ }^{3}$ K. Mukkanti, ${ }^{2}$ K. Suresh, ${ }^{1}$ \\ G. Madhusudhan, ${ }^{1}$ and Satish Nigam ${ }^{1}$ \\ ${ }^{1}$ Department of Research and Development, Inogent Laboratories Private Limited, 28A, IDA Nacharam, Hyderabad 500 076, India \\ ${ }^{2}$ Centre for Pharmaceutical Sciences, Institute of Science and Technology, Jawaharlal Nehru Technological University, \\ Kukatpally, Hyderabad 500 072, India \\ ${ }^{3}$ R\&D Centre, Orchid Chemicals and Pharmaceuticals Ltd., 476/14, Sholinganallur, Chennai 600 119, India
}

Correspondence should be addressed to G. Madhusudhan; madhusudhan.gutta@inogent.com

Received 27 June 2012; Revised 3 August 2012; Accepted 5 August 2012

Academic Editor: Michele Benedetti

Copyright (c) $2013 \mathrm{~K}$. Chandra Babu et al. This is an open access article distributed under the Creative Commons Attribution License, which permits unrestricted use, distribution, and reproduction in any medium, provided the original work is properly cited.

A practical and efficient enantioselective synthesis of antiepileptic drug, (-)-Levetiracetam, has been described in five steps (33.0\% overall yield) and high optical purity $(99.0 \% e e)$, using Evans asymmetric strategy for $\alpha$-alkylation of carbonyl functionality as the key step. The simplicity of the experimental procedures and high stereochemical outcome make this method synthetically attractive for preparing the target compound on multigram scales.

\section{Introduction}

Epilepsy is a chronic neurological disorder that consists of repeated occurrences of spontaneous seizures. Levetiracetam, [(S)-a-ethyl-2-oxopyrrolidine acetamide], (Figure 1) has recently been approved as an add-on therapy for the treatment of refractory epilepsy [1]. The $(S)$-enantiomer of etiracetam (levetiracetam) has shown remarkable pharmacokinetic and pharmacological activity which has led to the quick approval of this antiepileptic drug by the FDA. Levetiracetam offers several advantages over traditional therapy, including twice-daily dosing, a wide margin of safety with no requirements for serum drug concentration monitoring and no interactions with other anticonvulsants, and less adverse effects than traditional treatments [2-4].

Reported methods for the synthesis of levetiracetam typically involve chiral pool approaches starting from relevant enantiopure $\alpha$-amino acids [5-8], resolution of etiracetam or advanced racemic intermediates [5-10], asymmetric hydrogenation over $\mathrm{Rh}(\mathrm{I})$ or $\mathrm{Ru}(\mathrm{II})$ complexes $[11,12]$, and deracemization of 2-bromobutyric acid using $N$-phenyl pantolactam as a chiral auxiliary [13], proline catalyzed asymmetric $\alpha$-aminooxylation [14].

The synthesis of $\mathbf{1}$ has been previously reported by $S . P$. Kotkar, A. Sudalai using proline-catalyzed $\alpha$-aminooxylation of $n$-butyraldehyde in eight steps and $29.7 \%$ overall yield $^{7}$ and to the best of our knowledge Evans type chiral auxiliary directed entioselective synthesis of (-)-Levetiracetam has not yet been reported. Chiral auxiliary derived asymmetric $\alpha$ alkylation reactions have been identified as general method for asymmetric carbon-carbon bond formation [15, 16]. In this connection, Evans asymmetric strategy is the most powerful synthetic method that has been widely employed in natural product synthesis [17-23]. Moreover, the Evans type auxiliaries are inexpensive, nontoxic, available in both enantiomeric forms, and already explored for large scale synthesis of pharmaceutical important molecule like "Ezetimibe" (marketed as Zetia or Ezetrol) [24] antihyper lipidemic drug and "Tapentadol" (trade name Nucynta, in India Zyntap) is a centrally acting analgesic [25], and so forth.

In this paper, we report a practical and efficient enantio selective synthesis of levetiracetam, $\mathbf{1}$, in five steps with good overall yield using Evans type asymmetric $\alpha$-alkylation of 
<smiles>CC[C@@H](C(N)=O)N1CCCC1=O</smiles>

Levetiracetam, 1

FIGURE 1

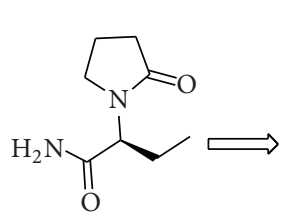

Levetiracetam, 1

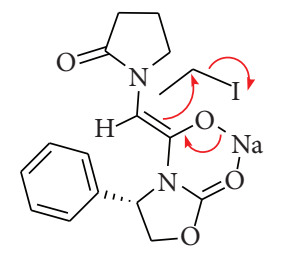

Z-enolate, compound 4

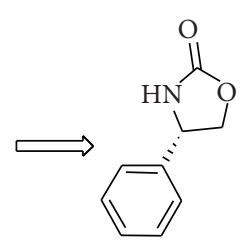

Evans auxilary
FIGURE 2: Retrosynthetic analysis of (-)-levetiracetam, 1.

compound 4. The retrosynthetic analysis of $\mathbf{1}$ is show in (Figure 2).

\section{Experimental Section}

All reagents and solvents employed were of commercial grade and were used as such, unless otherwise specified. Reaction flasks were oven-dried at $200^{\circ} \mathrm{C}$, flame-dried, and flushed with dry nitrogen prior to use. All moisture and airsensitive reactions were carried out under an atmosphere of dry nitrogen. TLC was performed on Kieselgel 60 F254 silica-coated aluminium plates (Merck) and visualized by UV light $(\lambda=254 \mathrm{~nm})$ or by spraying with a solution of $\mathrm{KMnO}_{4}$. Organic extracts were dried over anhydrous $\mathrm{Na}_{2} \mathrm{SO}_{4}$. Flash chromatography was performed using Kieselgel 60 brand silica gel (230-400 mesh). The melting points were determined in an open capillary tube using a Büchi B540 melting point instrument and were uncorrected. The IR spectra were obtained on a Nicolet 380 FT-IR instrument (neat for liquids and as $\mathrm{KBr}$ pellets for solids). NMR spectra were recorded with a Varian $300 \mathrm{MHz}$ Mercury plus Spectrometer at $300 \mathrm{MHz}\left({ }^{1} \mathrm{H}\right)$ and at $75 \mathrm{MHz}\left({ }^{13} \mathrm{C}\right)$. Chemical shifts were given in ppm relative to trimethylsilane (TMS). Mass spectra were recorded on Waters quattro premier XE triple quadrupole spectrometer using either electron spray ionization (ESI) or atmospheric pressure chemical ionization (APCI) technique.

2.1. Preparation of (S)-3-(2-Chloroacetyl)-4-phenyloxazolidin-2-one (3). A solution of chloroacetyl chloride $(9.76 \mathrm{~mL}$, $0.122 \mathrm{~mol})$ in DCM $(100.0 \mathrm{~mL})$ was added dropwise to a solution of (S)-4-phenyloxazolidin-2-one, $2(10.0 \mathrm{~g}, 0.61 \mathrm{~mol})$, $\mathrm{Et}_{3} \mathrm{~N}(35.0 \mathrm{~mL}, 0.244 \mathrm{~mol})$ and DMAP $(9.5 \mathrm{~g}, 4.0 \mathrm{~mol})$ in DCM $(150.0 \mathrm{~mL})$ while maintaining temperature at $0-5^{\circ} \mathrm{C}$. After $30 \mathrm{~min}$ additional chloroacetyl chloride was added ( 0.2 eq), and the mixture was gradually allowed to warm up to room temperature. After mixture was vigorously stirred for $1 \mathrm{~h}$, silica gel $(20.0 \mathrm{~g})$ was added and the reaction mixture was concentrated in vacuo. The resultant product was loaded on to a silica gel flash column. Elution with EtOAc/hexane $(1: 4)$ gave $(S)-3(10.26 \mathrm{~g}, 70 \%)$ as white solid. Mp: $108-110^{\circ} \mathrm{C}$. $[\alpha]_{\mathrm{D}}^{25}=-78.5\left[\mathrm{c} 1.0, \mathrm{CHCl}_{3}\right]$.

${ }^{1} \mathrm{H}-\mathrm{NMR}\left(400 \mathrm{MHz}, \mathrm{CDCl}_{3}\right): \delta 7.32-7.46(\mathrm{~m}, 5 \mathrm{H}), 5.45$ (dd, $J=3.9,8.7 \mathrm{~Hz}, 1 \mathrm{H}), 4.68-4.78(\mathrm{~m}, J=12.4 \mathrm{~Hz}, 3 \mathrm{H})$, $4.38(\mathrm{dd}, J=3.9,9.1 \mathrm{~Hz}, 1 \mathrm{H})$; IR $\left(\mathrm{CHCl}_{3}\right) v_{\max }: 1801,1717$, $695 \mathrm{~cm}^{-1}$; ESI-MS: $\mathrm{m} / z 239.1\left[\mathrm{M}^{+}+1\right]$.

2.2. Preparation of (S)-3-(2-(2-Oxopyrrolidin-1-yl)acetyl)-4phenyloxazolidin-2-one (4). Sodium hydride (60\% dispersion in oil, $5.4 \mathrm{~g}, 0.135 \mathrm{~mol}$ ) was added in small portions to a solution of 2-pyrrolidone $(10.6 \mathrm{~g}, 0.124 \mathrm{~mol})$ in DMF $(200.0 \mathrm{~mL})$ at room temperature and the mixture was stirred for $30 \mathrm{~min}$. To this mixture was added $3(25.0 \mathrm{~g}, 0.104 \mathrm{~mol})$, and the mixture was further stirred for another $30 \mathrm{~min}$. The reaction mixture was poured onto ice/water $(200.0 \mathrm{~mL})$ and extracted with methylene dichloride $(200.0 \mathrm{~mL})$. The extract was washed with brine, dried, and evaporated to dryness. The residue was subjected to silica gel column chromatography (eluent: AcOEt/hexane $1: 2)$ gave $4(27.0 \mathrm{~g}, 90 \%)$ as colorless solid. Mp: $173-175^{\circ} \mathrm{C} .[\alpha]_{\mathrm{D}}^{20}=-60.7[c=1.0, \mathrm{MeOH}]$.

${ }^{1} \mathrm{HNMR}\left(\mathrm{CDCl}_{3}, 300 \mathrm{MHz}\right): \delta 7.20-7.50(\mathrm{~m}, 5 \mathrm{H}), 5.40(\mathrm{t}$, $1 \mathrm{H}), 4.70(\mathrm{dd}, J=8.4,2.8 \mathrm{~Hz}, 1 \mathrm{H}), 4.50(\mathrm{dd}, J=17.0,1.4 \mathrm{~Hz}$, $1 \mathrm{H}), 4.25(\mathrm{dd}, J=10.4,1.4 \mathrm{~Hz}, 1 \mathrm{H}), 3.40(\mathrm{t}, 2 \mathrm{H}), 2.25(\mathrm{t}, 2 \mathrm{H})$, $2.00(\mathrm{~m}, 2 \mathrm{H}) ; \mathrm{IR}\left(\mathrm{CHCl}_{3}\right) v_{\max }: 2978,1779,1683,1071 \mathrm{~cm}^{-1}$; ESI-MS: $m / z 289.1\left[\mathrm{M}^{+}+1\right]$. Anal. calcd. for $\mathrm{C}_{15} \mathrm{H}_{16} \mathrm{~N}_{2} \mathrm{O}_{4}$ : C, 62.49; H, 5.59; N, 9.72; O, 22.20. Found: C, 62.85; H, 5.72; N, $9.98 ; \mathrm{O}, 22.65$.

2.3.4(S)-3-((S)-2-(2-Oxopyrrolidin-1-yl)butanoyl)-4-phenyloxazolidin-2-one (5). A cooled $\left(-78^{\circ} \mathrm{C}\right)$ solution of $(5.0 \mathrm{~g}$, $0.017 \mathrm{~mol}$ ) of 4 in $50.0 \mathrm{~mL}$ of dry tetrahydrofuran was added to a precooled $\left(-78^{\circ} \mathrm{C}\right)$ solution of $(26.0 \mathrm{~mL}, 0.026 \mathrm{~mol})$ of $1 \mathrm{M}$ sodium bis(trimethylsilyl)amide in toluene diluted with $60.0 \mathrm{~mL}$ of dry THF, keeping the temperature below $-60^{\circ} \mathrm{C}$. After $30 \mathrm{~min}$ at $-78^{\circ} \mathrm{C}$, a precooled solution of $(3.24 \mathrm{~g}, 0.020 \mathrm{~mol})$ of ethyl iodide in $40.0 \mathrm{~mL}$ of dry THF was added. After $2 \mathrm{~h}$ at $-75^{\circ} \mathrm{C}, 5.0 \mathrm{~mL}$ of glacial acetic acid was added and the mixture warmed immediately to $30^{\circ} \mathrm{C}$ for $1 \mathrm{~h}$. The solution was partitioned between methylene dichloride $(200.0 \mathrm{~mL})$ and dilute brine $(100.0 \mathrm{~mL})$. The aqueous phase was extracted with three $75.0 \mathrm{~mL}$ portions of methylene chloride. Combined organic extracts were washed with saturated $\mathrm{NaHCO}_{3}(100.0 \mathrm{~mL})$ and dried $\left(\mathrm{MgSO}_{4}\right)$, and concentrated. Chromatography on silica gel with $1: 9$ (ethyl acetate: methylene chloride) gave $\mathbf{5}(4.4 \mathrm{~g}, 81 \%)$ of product as a white solid. Mp: $121-123^{\circ} \mathrm{C} .[\alpha]^{20}{ }_{\mathrm{D}}=-87\left[\mathrm{c} 1.0, \mathrm{CHCl}_{3}\right]$.

${ }^{1} \mathrm{H} \mathrm{NMR}\left(\mathrm{CDCl}_{3}, 400 \mathrm{MHz}\right): \delta 7.32-7.41(\mathrm{~m}, 3 \mathrm{H})$, 7.26-7.28 (m, 2H), $5.63(\mathrm{~m}, 1 \mathrm{H}), 5.40(\mathrm{~m}, 1 \mathrm{H}), 4.73(\mathrm{t}, 1 \mathrm{H})$, $4.25(\mathrm{~m}, 1 \mathrm{H}), 3.66(\mathrm{~m}, 1 \mathrm{H}), 3.33(\mathrm{~m}, 1 \mathrm{H}), 2.46-2.32(\mathrm{~m}, 2 \mathrm{H})$, 2.10-1.95 (m, 3H), $1.67-1.55(\mathrm{~m}, 1 \mathrm{H}), 0.98(\mathrm{t}, 3 \mathrm{H}) \mathrm{ppm} ;{ }^{13} \mathrm{C}$ $\mathrm{NMR}\left(\mathrm{CDCl}_{3}, 75 \mathrm{MHz}\right): \delta 176.1,171.79,153.0,138.9,129.1$, 128.6, 125.5, 70.2, 57.3, 55.1, 44.4, 30.8, 22.3, 18.5, 11.0 ppm; IR (KBr) $v_{\max }: 2978,1779,1683,1226 \mathrm{~cm}^{-1}$; ESI-MS: $\mathrm{m} / z$ 

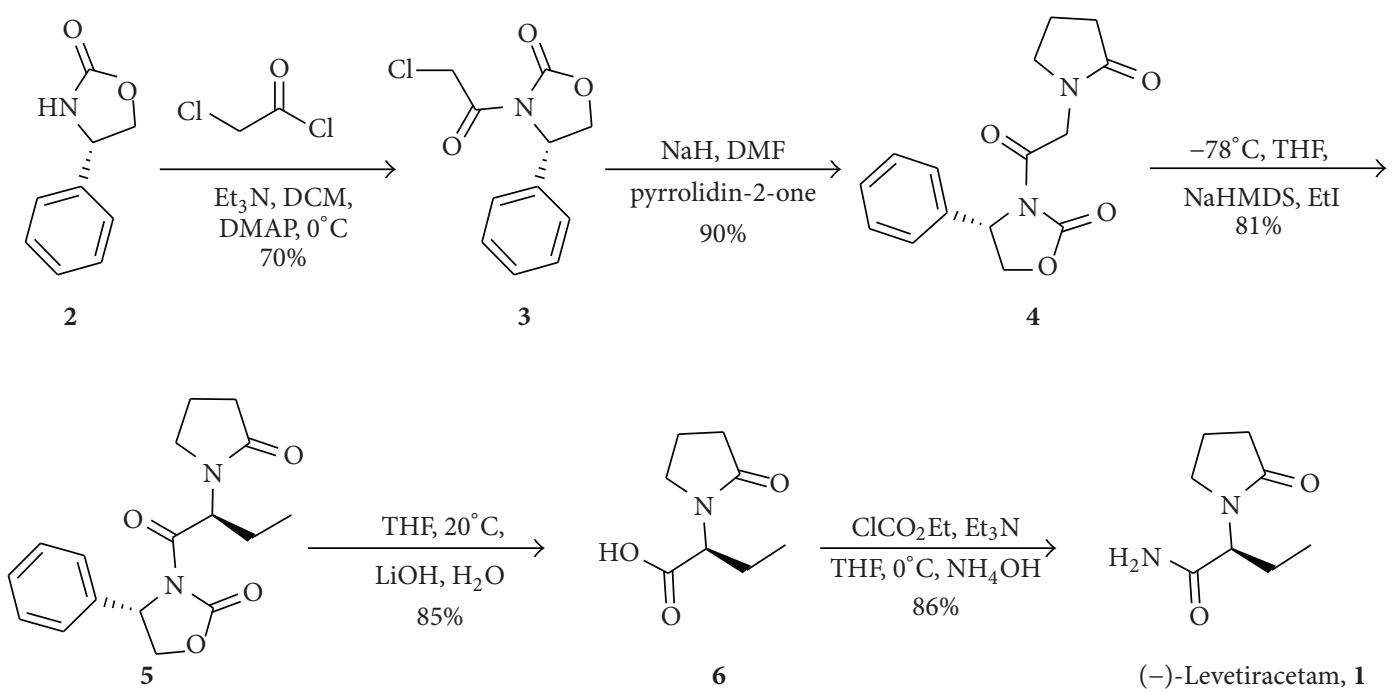

Scheme 1: Synthesis of (-)-Levetiracetam, 1.

317.2 $\left[\mathrm{M}^{+}+1\right]$. Anal. calcd. for $\mathrm{C}_{17} \mathrm{H}_{20} \mathrm{~N}_{2} \mathrm{O}_{4}$ : C, 64.54; $\mathrm{H}, 6.37$; N, 8.86; O, 20.23. Found: C, 64.96; H, 6.68; N, 8.97; O, 20.72.

2.4. Preparation of (S)-2-(2-Oxopyrrolidin-1-yl)butanoic Acid (6). To a cold $\left(0^{\circ} \mathrm{C}\right)$ solution of $5(5.0 \mathrm{~g}, 0.015 \mathrm{~mol})$ in THF $(30.0 \mathrm{~mL}), 30 \% \mathrm{w} / \mathrm{v} \mathrm{H}_{2} \mathrm{O}_{2}(8.5 \mathrm{~mL}, 0.074 \mathrm{~mol})$, and $\mathrm{LiOH} / \mathrm{H}_{2} \mathrm{O}(1.13 \mathrm{~g}, 0.047 \mathrm{~mol})$ were added sequentially and the mixture was stirred at this temperature for $7 \mathrm{~h}$. A solution of $\mathrm{Na}_{2} \mathrm{SO}_{3}(75.0 \mathrm{~mL})$ was added, the final $\mathrm{pH}$ being about 9. This mixture was extracted with Methylene dichloride $(150 \mathrm{~mL})$, was then it discarded and the aqueous phase was made acidic $(\mathrm{pH}=2-3)$ with $1 \mathrm{M} \mathrm{HCl}$ and subsequently extracted with AcOEt $(150 \mathrm{~mL})$. The combined AcOEt organic extracts were dried over $\mathrm{Na}_{2} \mathrm{SO}_{4}$ and concentrated in vacuo. to give $(S)-6(2.3 \mathrm{~g}, 85 \%)$ as a white solid. Mp: $124-125^{\circ} \mathrm{C} .[\alpha]_{\mathrm{D}}^{25}=-24.3[\mathrm{c}$ l.0, acetone $]$.

${ }^{1} \mathrm{H} \mathrm{NMR}\left(\mathrm{CDCl}_{3}, 400 \mathrm{MHz}\right): \delta 4.64(\mathrm{dd}, J=10.6,4.8 \mathrm{~Hz}$, $1 \mathrm{H}), 3.52-3.58(\mathrm{~m}, 1 \mathrm{H}), 3.37(\mathrm{~m}, J=8.7,5.8 \mathrm{~Hz}, 1 \mathrm{H}), 2.49(\mathrm{t}$, $J=7.7 \mathrm{~Hz}, 2 \mathrm{H}), 1.99-2.13(\mathrm{~m}, 3 \mathrm{H}), 1.67-1.76(\mathrm{~m}, 1 \mathrm{H}), 0.93$ $(\mathrm{t}, J=7.7 \mathrm{~Hz}, 3 \mathrm{H}) \mathrm{ppm} ;{ }^{13} \mathrm{CNMR}\left(\mathrm{CDCl}_{3}, 75 \mathrm{MHz}\right): \delta 177.1$, 173.7, 55.4, 43.8, 30.7, 21.8, 18.1, $10.7 \mathrm{ppm} ; \mathrm{IR}\left(\mathrm{CHCl}_{3}\right) v_{\max }$ : 2975, 2358, 1731, $1620 \mathrm{~cm}^{-1}$; ESI-MS: $\mathrm{m} / z 170.0\left[\mathrm{M}^{-}+1\right]$.

2.5. Preparation of (S)-2-(2-Oxopyrrolidin-1-yl)butanemide $\left(1\right.$, Levetiracetam). To a cold $\left(0^{\circ} \mathrm{C}\right)$ solution of acid $(S)-6$ $(5.0 \mathrm{~g}, 0.292 \mathrm{~mol})$ and $\mathrm{Et}_{3} \mathrm{~N}(4.3 \mathrm{~mL}, 0.307 \mathrm{~mol})$ in anhydrous THF $(20 \mathrm{~mL})$ was added ethylchloroformate $(2.9 \mathrm{~mL}$, $0.304 \mathrm{~mol}$ ) and the mixture stirred at $0^{\circ} \mathrm{C}$ for $30 \mathrm{~min}$. Ammonium hydroxide $(25 \% \mathrm{w} / \mathrm{v}$ aqueous solution, $19.0 \mathrm{~mL})$ was added and the reaction mixture was left to stir at room temperature for $12 \mathrm{~h}$. After the addition of $\mathrm{K}_{2} \mathrm{CO}_{3}(4.14 \mathrm{~g}$, $30.0 \mathrm{~mol}$ ), the mixture was filtered and the volatile materials (solvent and $\mathrm{Et}_{3} \mathrm{~N}$ ) distilled off in vacuo. The solid residue was extracted with methylene dichloride $(150 \mathrm{~mL})$ and the combined organic extracts dried over $\mathrm{Na}_{2} \mathrm{SO}_{4}$ and concentrated in vacuo recrystallization from acetone $(100.0 \mathrm{~mL})$ gave $\mathbf{1}$ $(4.3 \mathrm{~g}, 86 \%)$ a white solid. Mp: $113-114^{\circ} \mathrm{C} .[\alpha]^{25}{ }_{\mathrm{D}}=-95.0[c$ $=1.0$, acetone $]$.

${ }^{1} \mathrm{H} \mathrm{NMR}\left(\mathrm{CDCl}_{3}, 400 \mathrm{MHz}\right): \delta 6.50$ (br s, $\left.1 \mathrm{H}\right), 5.70$ (br s, $1 \mathrm{H}), 4.50(\mathrm{t}, J=8.7,6.8 \mathrm{~Hz}, 1 \mathrm{H}), 3.48(\mathrm{~m}, 2 \mathrm{H}), 2.50$ $(\mathrm{m}, 2 \mathrm{H}), 1.98-2.20(\mathrm{~m}, 3 \mathrm{H}), 1.70(\mathrm{~m}, 1 \mathrm{H}), 0.98(\mathrm{t}, J=$ $7.7 \mathrm{~Hz}, 3 \mathrm{H}) \mathrm{ppm} ;{ }^{13} \mathrm{CNMR}\left(\mathrm{CDCl}_{3}, 75 \mathrm{MHz}\right): \delta 175.9,172.7$, 55.9, 43.7, 31.0, 21.2, 18.0, $10.4 \mathrm{ppm}$; IR $\left(\mathrm{CHCl}_{3}\right) v_{\max }$ : 3200, 1731, $1620 \mathrm{~cm}^{-1}$; ESI-MS: $\mathrm{m} / z 171.0\left[\mathrm{M}^{+}+1\right]$. Anal. calcd. for $\mathrm{C}_{8} \mathrm{H}_{14} \mathrm{~N}_{2} \mathrm{O}_{2}$ : C, 56.45; H, 8.29; N, 16.46; O, 18.80. Found: C, 56.76; H, 8.52; N, 16.87; O, 19.26. Chiral HPLC purity 99\% ee. The enantiomeric excess was determined by HPLC analysis in comparison with authentic racemic material and HPLC conditions: Chiral OD-H column; hexane: $\mathrm{i}-\mathrm{PrOH}$ $(90: 10 \mathrm{v} / \mathrm{v})$; flow rate $1.0 \mathrm{~mL} / \mathrm{min}$; UV $-210 \mathrm{~nm}$; column temperature $25^{\circ} \mathrm{C}$; CHIRAL HPLC purity: $t_{r}=14.4 \mathrm{~min}(S)$ isomer (major enantiomer) and $9.3 \mathrm{~min}(R)$-isomer (minor enantiomer).

\section{Results and Discussion}

As shown in (Scheme 1), the synthesis of (-)-levetiracetam, 1, was started from acylation of Evans type auxiliary $(S)$ 4-phenyloxazolidin-2-one, 2, with chloroacetyl chloride in the presence of $\mathrm{Et}_{3} \mathrm{~N}$ in methylene chloride using DMAP to afford (S)-3-(2-chloroacetyl)-4-phenyloxazolidin-2-one, 3 , in $70 \%$ yield. Reaction of $\mathbf{3}$ with 2 -pyrrolidone in the presence of sodium hydride $(\mathrm{NaH})$ in dimethyl formamide (DMF) to furnish (S)-3-(2-(2-oxopyrrolidin-1-yl)acetyl)-4phenyloxazolidin-2-one, 4 , in $90 \%$ yield; $[\alpha]_{\mathrm{D}}^{20}=-60.7$ $(c=1.0, \mathrm{MeOH})$. The diastereo selective alkylation on compound 4 was carried out using NaHMDS and ethyl iodide in dry THF at $-78^{\circ} \mathrm{C}$ gave 5 in $81 \%$ yield with excellent diastereoselectivity; $[\alpha]_{\mathrm{D}}^{20}=-87.0\left(c=1.0, \mathrm{CHCl}_{3}\right)$. 
TABLE 1: Diastereoselective $\alpha$-alkylation of $\mathbf{4 a} \& \mathbf{4 b}$.

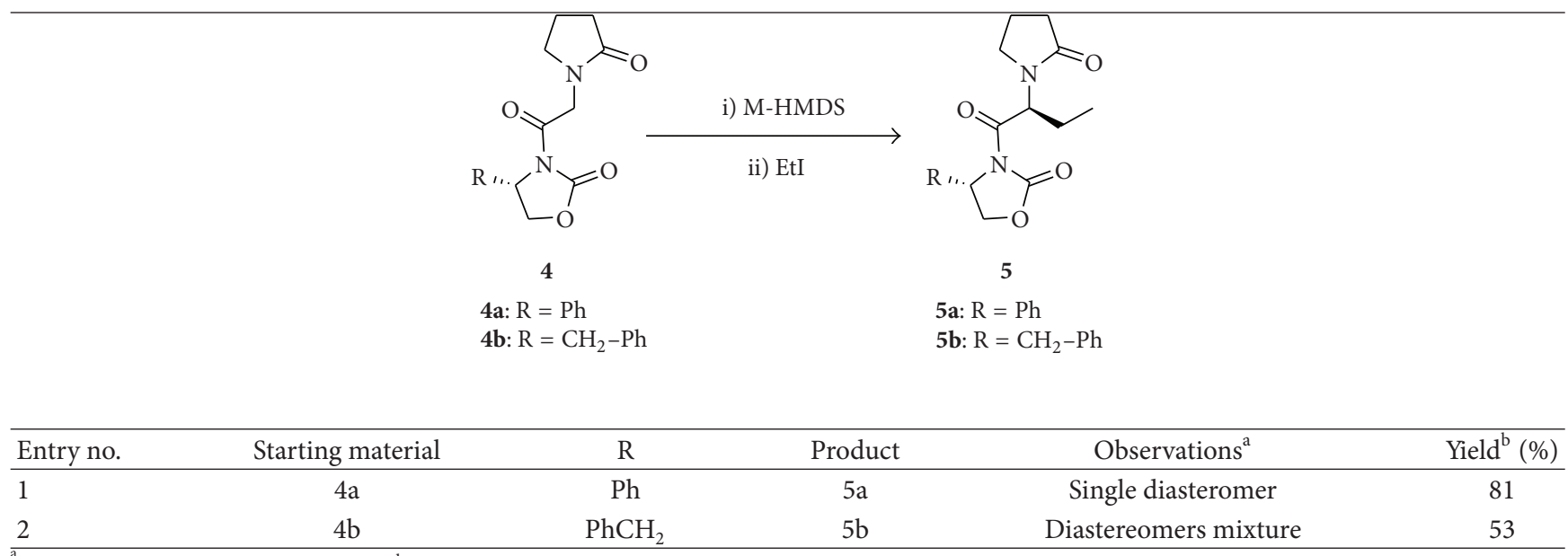

abserved by monitoring on TLC and ${ }^{\mathrm{b}}$ isolated yield after purification.

The alkylation had indeed occurred from the least hindered face of the enolate delivering the required $\mathbf{S}$ stereochemistry.

3.1. Study of Selectivity during Alkylation with respect to Auxiliary and Size of Metal Ion. The discrepancy of stereoselectivity during $\alpha$-alkylation with respect to substitution of auxiliary and size of metal ion was studied. The enolate derived from $\mathbf{4 a} \& \mathbf{4} \mathbf{b}$ with NaHMDS was alkylated under same conditions with ethyl iodide and the results are summarized in (Table 1).

$(S)$-phenyl substituted auxiliary showed higher diastereoselectivity (99\% ee) as compared to (S)-benzyl auxiliary $(<85 \%$ ee) with NaHMDS as the base, the diastereomeric ratios during alkylation were determined by chiral HPLC purity of final product (-)-Levetiracetam, 1. Whereas LiHMDS provided similar results with $\mathbf{4 a} \& \mathbf{4} \mathbf{b}$, but not as well as those with NaHMDS. Removal of the chiral auxiliary in compound 5 was carried out by $\mathrm{LiOH} / \mathrm{H}_{2} \mathrm{O}_{2}$ in THF to afford the corresponding acid $\mathbf{6}$ in $85 \%$ yield. This is particularly noteworthy in a way that the $(S)$-4-phenyloxazolidin-2-one could be recovered in $85 \%$ yield, after a simple acid-base workup operation. Acid $\mathbf{6}$ on treatment with ethyl chloroformate and ammonium hydroxide produced (-)-Levetiracetam, $\mathbf{1}$, in $86 \%$ yield and $99.0 \%$ ee (determined by chiral HPLC analysis). The spectral data which were found to be in good agreement with reported values [26].

\section{Conclusion}

In conclusion, a practical and efficient enantioselective synthesis of levetiracetam, 1, has been achieved successfully by employing Evans type asymmetric strategy. The merit of the mentioned approach is less number of steps (5 steps), improved overall yield (33.0\%) and high enantioselectivity $(\mathbf{9 9 . 0} \% \mathrm{ee})$. This sequence has also been applied to the preparation of the enantiomer of levetiracetam and brivaracetam, and so forth. The simplicity of the experimental procedures and high stereochemical outcome make this method synthetically attractive for preparing the target compound on multigram scales and industrial applications. See Supplementary Material available online at doi:10.1155/2013/176512, including copies of the ${ }^{1} \mathrm{H},{ }^{13} \mathrm{C}$ NMR, Mass, IR spectra of the new compounds.

\section{Acknowledgment}

The authors thank Inogent Laboratories Private Limited (A GVK BIO Company) for the financial support and encouragement.

\section{References}

[1] B. Hurtado, M. J. Koepp, J. W. Sander, and P. J. Thompson, "The impact of levetiracetam on challenging behavior," Epilepsy and Behavior, vol. 8, no. 3, pp. 588-592, 2006.

[2] M. Dooley and G. L. Plosker, "Levetiracetam: a review of its adjunctive use in themanagement of partial onset seizures," Drugs, vol. 60, no. 4, pp. 871-893, 2000.

[3] C. A. Hovinga, "Levetiracetam: a novel antiepileptic drug," Pharmacotherapy, vol. 21, no. 11, pp. 1375-1388, 2001.

[4] S. D. Shorvon and K. Van Rijckevorsel, "A new antiepileptic drug," Journal of Neurology Neurosurgery and Psychiatry, vol. 72, no. 4, pp. 426-429, 2002.

[5] J. Gobert, J. P. Greets, and G. Bodson, European Patent Application, E0162036, Chemistry Abstract 105, 018467.

[6] B. Z. Dolityzky, PCT International Application, WO, 2004/ 069796, Chemistry Abstract 133, 183002, 2004.

[7] C. Ates, J. Surtees, A. C. Burteau, V. Marmon, and E. Cavoy, PCT International Application, WO, 2003/014080, Chemistry Abstract 138, 170071, 2003.

[8] E. Cossement, G. Motte, J. P. Geerts, and J. Gobert, UK Patent Application, GB, 2225322, Chemistry Abstract 113, 191151.

[9] T. Futagawa, J. P. Canvat, E. Cavoy, M. Deleers, M. Hamende, and V. Zimmermann, US Patent 2000/6107492, Chemistry Abstract 133, 183002, 2000. 
[10] E. Cavoy, M. Hamende, M. Deleers, J. P. Canvat, and V. Zimmermann, US Patent 2000/6124473, Chemistry Abstract 133, 268549, 2000.

[11] J. Surtees, V. Marmon, E. Differding, and V. Zimmermann, PCT International Application WO, 2001/64637, 2001.

[12] N. W. Boaz and S. D. Debenham, PCT International Application, WO 2002/26705, Chemistry Abstract 136, 279566, 2002.

[13] F. Boschi, P. Camps, M. Comes-Franchini, D. Muñoz-Torrero, A. Ricci, and L. Sánchez, "A synthesis of levetiracetam based on $(S)-N$-phenylpantolactam as a chiral auxiliary," Tetrahedron Asymmetry, vol. 16, no. 22, pp. 3739-3745, 2005.

[14] S. P. Kotkar and A. Sudalai, "A short enantioselective synthesis of the antiepileptic agent, levetiracetam based on prolinecatalyzed asymmetric $\alpha$-aminooxylation," Tetrahedron Letters, vol. 47, no. 38, pp. 6813-6815, 2006.

[15] J. S. Penne, Chiral Auxiliaries and Ligands in Synthesis, John Wiley \& Sons, New York, NY, USA, 1995.

[16] R. E. Gawley and J. Aube, "Principles of asymmetric synthesis," in Tetrahedron Organic Chemistry Series, J. E. Baldwin and P. D. Magnus, Eds., vol. 14, Elsevier Press, Oxford, UK, 1996.

[17] D. J. Ager, I. Prakash, and D. R. Schaad, "Chiral oxazolidinones in asymmetric synthesis," Aldrichimica Acta, vol. 30, no. 1, pp. 3-12, 1997.

[18] D. A. Evans, J. Bartroli, and T. L. Shih, "Enantioselective Aldol condensations. 2. Erythro-selective chiral Aldol condensations via boron enolates," Journal of the American Chemical Society, vol. 103, no. 8, pp. 2127-2129, 1981.

[19] D. A. Evans, K. T. Chapman, D. T. Hung, and A. T. Hawaguchi, "Transition state $\pi$-solvation by aromatic rings: an electronic contribution to diels-alder reaction diastereoselectivity," Angewandte Chemie International Edition in English, vol. 26, pp. 1184-1186, 1987.

[20] I. W. Davies, C. H. Senanayake, L. Castronguay, R. D. Larsen, T. R. Verhoeven, and P. J. Reider, "Highly diastereoselective DielsAlder reaction mediated by a chiral auxiliary derived from amino indanol: the role of conformation on diastereoselectivity," Tetrahedron Letters, vol. 36, no. 42, pp. 7619-7622, 1995.

[21] M. A. Walker and C. H. Heathcock, "Acyclic stereoselection. 54. Extending the scope of the evans asymmetric aldol reaction: preparation of anti and "non-evans" syn aldols," Journal of Organic Chemistry, vol. 56, no. 20, pp. 5747-5750, 1991.

[22] D. A. Evans, M. T. Bilodeau, T. C. Somers, J. Clardy, D. Cherry, and Y. Kato, "Enantioselective Michael reactions. Diastereoselective reactions of chlorotitanium enolates of chiral $\mathrm{N}$-acyloxazolidinones with representative electrophilic olefins," Journal of Organic Chemistry, vol. 56, no. 20, pp. 5750-5752, 1991.

[23] G. Li, K. C. Russell, M. A. Jarosinski, and V. J. Hruby, "Asymmetric synthesis of unusual amino acids: an enantioselective synthesis of the four isomers of D- and L-O-methyl-2', $\beta$ dimethyltyrosine," Tetrahedron Letters, vol. 34, no. 16, pp. 2565-2568, 1993.

[24] C. H. V. A. Sasikala, P. R. Padi, V. Sunkara et al., "An improved and scalable process for the synthesis of ezetimibe: an antihypercholesterolemia drug," Organic Process Research and Development, vol. 13, no. 5, pp. 907-910, 2009.

[25] Q. Zhang, J.-F. Li, G.-H. Tian et al., "A practical and enantioselective synthesis of tapentadol," Tetrahedron Asymmetry, vol. 23, no. 8, pp. 577-582, 2012.

[26] T. Imahori, K. Omoto, Y. Hirose, and H. Takahata, "Asymmetric synthesis of the antiepileptic drug levetiracetam," Heterocycles, vol. 76, no. 2, pp. 1627-1632, 2008. 

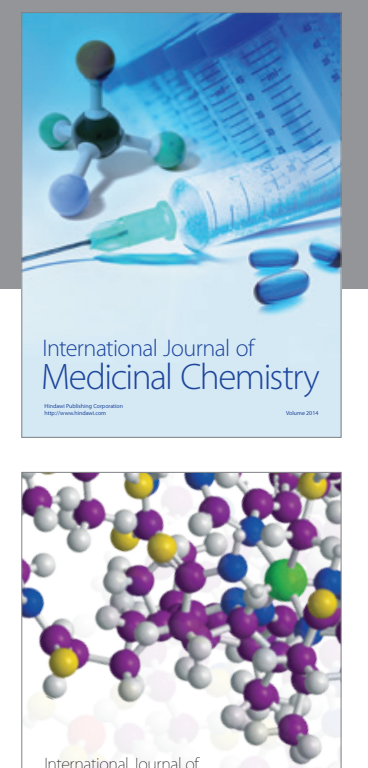

\section{Carbohydrate} Chemistry

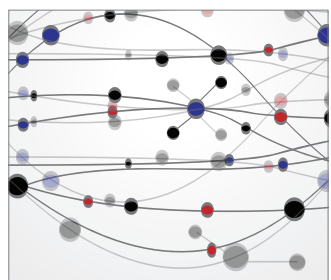

The Scientific World Journal
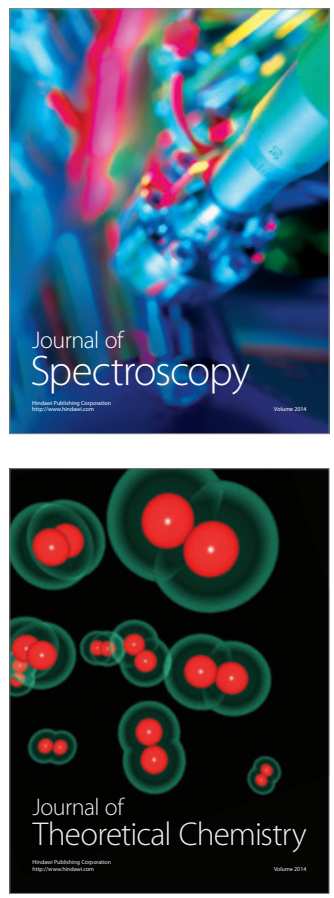
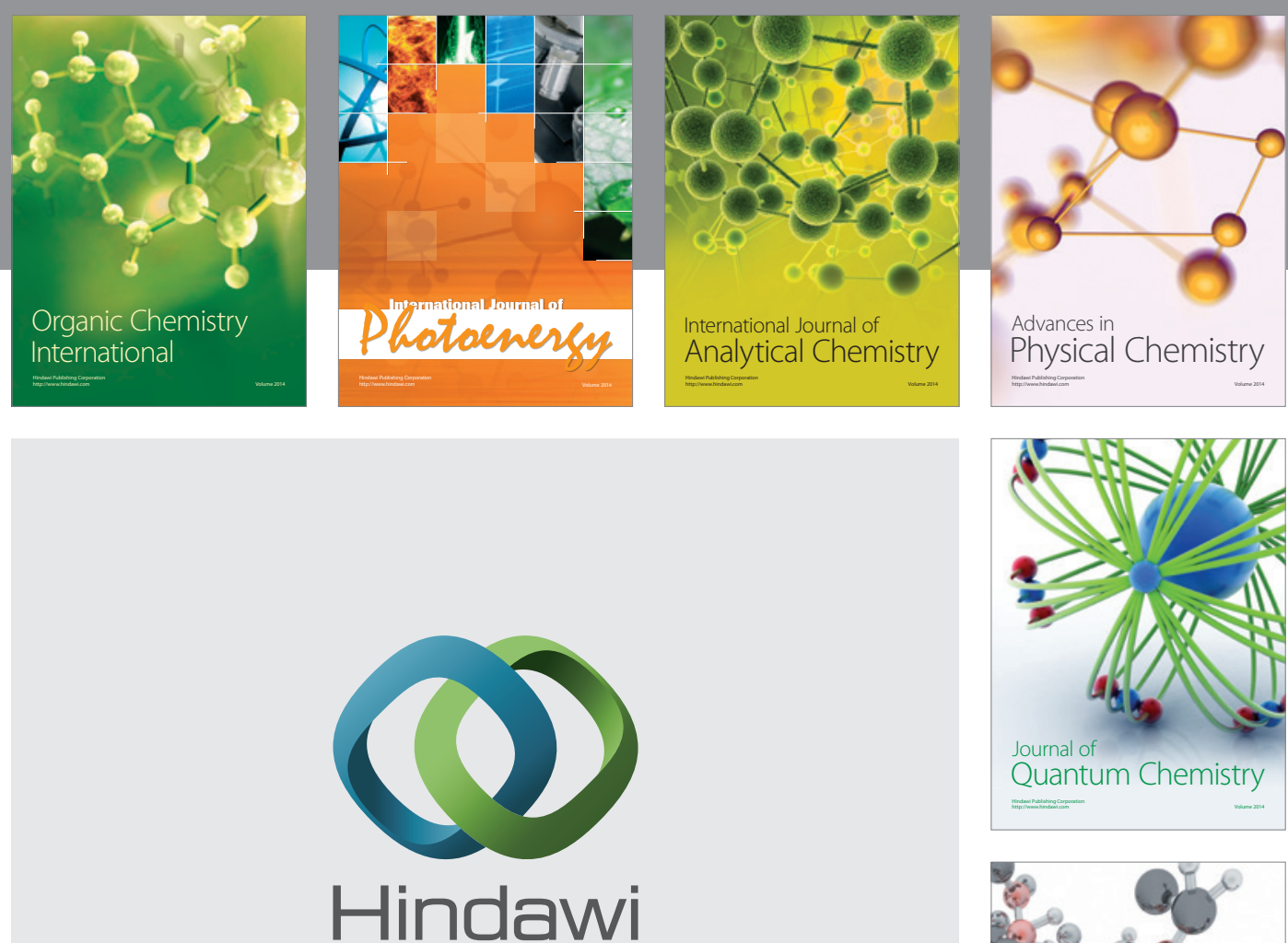

Submit your manuscripts at

http://www.hindawi.com

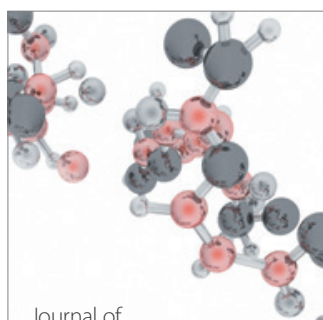

Analytical Methods

in Chemistry

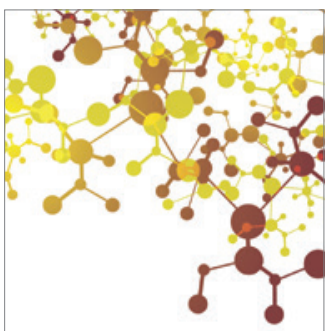

Journal of

Applied Chemistry

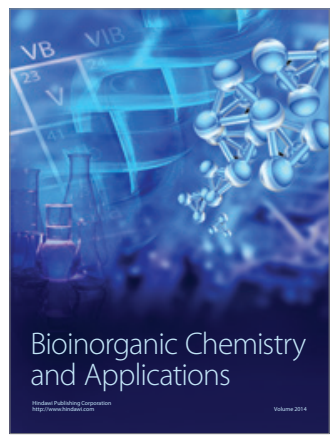

Inorganic Chemistry
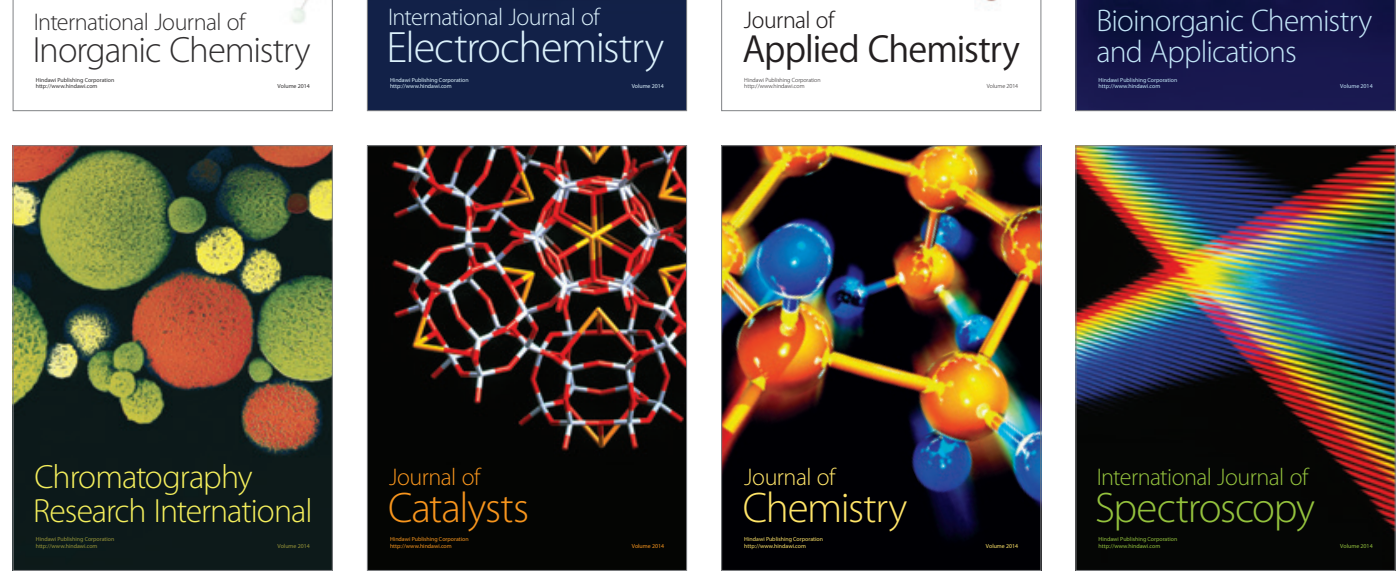